\title{
"To Thine Own Self Be True": Existentialism in Hamlet and The Blind Owl
}

\author{
Masoud Farahmandfar \\ Shahid Beheshti University, Iran \\ Gholamreza Samigorganroodi \\ Fanshaw College, Canada
}

Received: 26-01-2015

Accepted: 29-02- 2015

Published: 01-04- 2015

doi:10.7575/aiac.ijclts.v.3n.2p.25

URL: http://dx.doi.org/10.7575/aiac.ijclts.v.3n.2p.25

\begin{abstract}
This article aims at exploring the key concepts of Existential thought in two masterpieces of the world literature, namely, William Shakespeare's Hamlet and Sadeq Hedayat's The Blind Owl (Buf-e Kur). Freedom, free will, authenticity, self-realization, self-becoming, and awareness of death are among the main concerns of both writers. Shakespeare depicts authenticity in the character of Hamlet, and it is in contrast to him that the reader finds many instances of inauthenticity. The Danish prince has no tolerance whatsoever for inauthentic or self-deceiving. The same thing is visible in The Blind Owl in which the narrator-protagonist feels himself above all the low, petty desires of mankind. All in all, both characters' main challenge is to live authentically.
\end{abstract}

Keywords: Existential philosophy, authenticity, angst, death, being, existence, self-realization

\section{Introduction}

"The whole philosophy is only a meditation on Shakespeare."

-Emmanuel Levinas, Time and the Other

Shakespeare's works have shaped many philosophical issues and thoughts; Freud took many of his examples from Shakespeare to support and propound his ideas; ${ }^{i}$ Kierkegaard, Nietzsche and Emerson ${ }^{\mathrm{ii}}$ were indeed post-Shakespeareans. Without Shakespeare, many modern thinkers would have been lost. They have appropriated Shakespeare into their own ideas and philosophies.

In recent years, most of Shakespearean criticisms have been concerned either with new historical, cultural materialist readings, or with Lacanian psychoanalytic ones. However, it is not inappropriate to step out of this hubbub of contemporary theory and open the window of Shakespearean studies to such basic issues as freedom, free will, authenticity and self-becoming-key concepts lying at the heart of existential thought. Usually, most people relate these notions to the philosophy of Kierkegaard or Heidegger or the literary writings and pensees of Sartre and Camus. However, one can trace these concepts back to the early modern era and in the works of the most celebrated writer of that period, William Shakespeare (1564-1616). This research attempts, first, to define 'existential' thought and expound its fundamental concepts and, then, to follow these key concepts in Hamlet, the most renowned and most quoted of Shakespearean plays, because "Hamlet demands a more inward response to its main character" (Holbrook, 2010: 47). The writers also claim that the same themes and motifs recur in Sadeq Hedayat's novel The Blind Owl. If Hamlet-mostly regarded as the greatest work in English literature-shows existential concerns, the same concerns are visible in The Blind Owl, the greatest work in modern Persian fiction. And exploring these concerns in these two remarkable literary works defines the purpose of the present research.

\section{Discussion}

\subsection{Existentialism: "Being that we ourselves are",iii}

It is not easy to define 'existentialism' in a few sentences or pages. ${ }^{\text {iv }}$ In fact, we preferably should speak of Existentialisms. Marjorie Grene in her book, Introduction to Existentialism $(1948$ - first published as Dreadful Freedom) declares, "nearly every philosopher since Hegel is shown to be in some sense an existentialist" (2), and she continues that existentialism is not a finished process, wrapped up and archived for good. Rather, we are still (and will forever be) wrestling with its principal ideas. Therefore, it is preferable to take '-ism' away from it in order not to limit or bound it to a particular time and place.

Thomas Flynn (2006) enumerates the basic themes of existential thought as follows: 
a. Existence precedes essence: "What you are (your essence) is the result of your choices (your existence) rather than the reverse. Essence is not destiny. You are what you make yourself to be" (8).

b. Humanism: "Existentialism is a person-centered philosophy. Though not anti-science, its focus is on the human individual's pursuit of identity and meaning ..." (Ibid.).

c. Freedom/Responsibility: "Existentialism is a philosophy of freedom. Its basis is the fact that we can stand back from our lives and reflect on what we have been doing. In this sense, we are always 'more' than ourselves. But we are as responsible as we are free" (Ibid. 8-10).

d. Authenticity: being true to oneself and avoiding 'bad faith' (mauvaise foi). It is the way human beings come to know themselves. Bad faith is self-deception. In Hamlet, Polonius advises his son "This above all: to thine own self be true / And it must follow, as the night the day / Thou canst not then be false to any man" (I. iii. 78-80). Authenticity (eigentlich) is reflected in the integrity of character-the very thing Hamlet strives to maintain. For Hedayat, this authenticity is only possible when people constantly remind themselves that they will die someday and there is no escape from it; then, they can be true to themselves. As the narrator in The Blind Owl says, "Only death does not lie. [...] It is death that rescues us from the deceptions of life" (Hedayat, 2010 [1937]: 84).

Existential thought emphasizes the value of self-knowing, self-becoming and individualism. These ontological concerns also knit many of Shakespeare's plays and many literary pieces of Hedayat. As Lashgari (1982) maintains, "Hedayat's stories are full of characters who are not sure who or what they are. The desire for self-realization appears most directly in the story 'Tarik-khaneh' ['The Dark Room']" (3152). And Shakespeare's serious attention to the question of self-knowing alone makes him an existentialist avant la letter.

Another important point is to distinguish existential philosophy from the absurd movement (of the 195060s). The ready-made, superficially appealing ideas of absurdity-'life has no purpose', 'we are abandoned', 'there is no God or any other supreme power to guide or control us', and many other jaundiced (pseudo-existentialist) statements of this kind that not only upset human beings but exacerbate their existence-are not visible in Shakespeare's oeuvre. Shakespeare's worldview discards these kinds of quick counterfeit answers that advertise irresponsibility and passivity. To live with/by this fake belief system is to live in 'bad faith'. A famous example of bad faith is seen in Shakespeare's King Lear in the character of Gloucester who is blind to his mischief and wrongly imposes his failures to the will of gods: "As flies to wanton boys are we to the gods / They kill us for their sport" (IV. i. 37-8). For some of Shakespeare's characters, as long as there is a choice, there is a way, and no one is inherently denied of that. It is not in the stars to hold our destiny but in ourselves: "[Cassius:] The fault, dear Brutus, is not in our stars / But in ourselves" (Julius Caesar, I. ii. 140-1). In fact, Shakespeare loved dramatizing the self in distress, in moments of crisis. If a character survives such an ordeal, $\mathrm{s} / \mathrm{he}$ is authentic (and will find salvation). Some may say the lovers in Romeo and Juliet are 'star-crossed' and therefore, in a reductionist manner, conclude that the bard is fatalist; however, we should be wary not to follow them into using these convenient labels. Romeo gives in to fate because - unlike Hamlet - he has lost his self. (Unlike Hamlet, he does not "suffer the slings and arrows of outrageous fortune" and does not "by opposing end them," instead he ends his life.) As Romeo himself says, "I have lost myself. I am not here. / This is not Romeo" (I. i. 190-191). Indeed, "salvation [is] made to depend on the unflinching recognition of the ultimate reality of nothingness" (Glicksberg, 1948: 232). An existential hero can face the Curtzian moment of 'the horror! The horror!' and "transcend the horror of nothingness" (Ibid.). Moreover, the passage from Romeo and Juliet to Hamlet is a passage from the medieval separation-romance to the Renaissance humanistic pensée on the 'being that we ourselves are'. This passage (or transition, if you prefer) is also one from the Hebraic attitude to the Hellenic viewpoint. ${ }^{\mathrm{v}}$

On the whole, contrary to recent cultural theories ${ }^{\mathrm{vi}}$, existential thought maintains that human beings (as beings en soi and pour soi) are not merely the construct or the product of their historio-socio-cultural conditions of their time. Rather, the way they respond to the world around them is of their own choosing. They are not trapped within the Foucauldian discourse, nor their 'I's have already lost their agency. In brief, action and responsibility, to existentialists, rest entirely with and upon the individual. This brings us to the idea of individualism.

\subsection{Individualism}

The age of Shakespeare was an age of expansion and colossal changes (paradigm shift). Feudalism was on the decline and the unprecedented growth of markets was paving the way for the arrival of a semi-capitalist system. Moreover, the Reformation and also Humanism, with their emphasis on the value of individual self, were becoming the dominant discourse. The humanism of the Essays of Montaigne and pursuing personal benefit in Machiavelli's Prince are but two instances of the growing sense of individualism. Shakespeare was familiar with these works. His emphasis on the inward life of his dramatic characters (e.g. Macbeth) and the struggles of mind to remain true to itself in the face of existential angst (Hamlet) foreshows the existential emphasis on the self ("What a piece of work is a man" [Hamlet, II. ii. 299]). Also, Hedayat refers 
to human being as a "miniature of God" who can transcend the "mean, paltry needs of mankind" and feel within himself the "flux of eternity" (99).

\section{Analysis}

\section{Hamlet, the Existential Hero}

"Hamlet's long significance for Western culture has a simple cause. The play is committed to individual freedom" (Holbrook, 2010: 68). The play begins with the question "Who's there?" in order to engrave the significance of the idea of 'identity' in the reader's mind. This brief opening line, as such, is primarily Hamlet's question about himself, for his basic ontological question throughout the play is "Who am I?"

Like Camus' stranger, Hamlet is an existential alienated ${ }^{\text {vii }}$ hero whose self-consciousness drives him to dwell and muse upon the condition of human existence and his own situation in an 'out-of-joint' world which, for him, is no more than an "unweeded garden / That grows to seed: things rank and gross in nature" (I. ii. 135-7). Throughout the play, Hamlet is concerned with the question of how to act. He is condemned to choose. His is a self-defining choice, since man is the result of the choices he makes. And Hamlet's choice is:

To be, or not to be: that is the question

Whether 'tis nobler in the mind to suffer

The slings and arrows of outrageous fortune

Or to take arms against a sea of troubles,

And by opposing end them? To die, to sleep

No more, and by a sleep to say we end

The heart-ache and the thousand natural shocks

That flesh is heir to. 'Tis a consummation

Devoutly to be wished. To die, to sleep -

To sleep, perchance to dream: ay, there's the rub,

For in that sleep of death what dreams may come

When we have shuffled off this mortal coil ... (III. i.)

In The Myth of Sisyphus (2005 [1942]), Camus declares that the question of 'why should I continue to live?' is "one truly serious philosophical problem". Hamlet's famous soliloquy, his existential quandary, "to be (authentically) or not to be", is such a question. Examining non-existence leads him to self-consciousness: "The return to consciousness, the escape from everyday sleep represents the first steps of absurd freedom" (57).

As we discussed earlier, authenticity is an important issue in existential thought (and also in Shakespeare's Hamlet). Shakespeare depicts authenticity in the character of Hamlet, and it is in contrast to him that the reader finds many instances of inauthenticity. The Danish prince has no tolerance whatsoever for inauthentic or self-deceiving people (e.g. Rosencrantz, Gildenstern, Osric ..., inauthentic people which Heidegger calls them Das Man). For instance, Hamlet does not kill Claudius when he is praying because it would not be an authentic act of revenge, while Claudius unfairly poisons Laertes' sword to wipe out Hamlet. Also, Hamlet refers to Osric as a "water-fly" who plays the tune of the time (V. ii). The likes of him are instruments to be played upon (III. ii). Hamlet is extremely furious when it comes to fraudulence and insincerity:

I have heard of your paintings too, well enough.

God has given you one face, and you make yourselves another.

You jig, you amble, and you lisp, and nickname God's

creatures, and make your wantonness your ignorance. Go

to, I'll no more on 't; it hath made me mad. (III. i. 141-5, emphasis added)

Hamlet, on the other hand, struggles to remain 'authentic', not to conform to fatuous habits or customs-the habits or customs demand him not to mourn for his dead father; they demand that he rejoices at the marriage of his late father's widow, even though he found it temerarious. Hamlet believes it is more honorable to break these feigned customs than to abide by them:

\section{Horatio: "Is it a custom?}

Hamlet: Ay, marry, it is,

But to my mind, though I am native here

And to the manner born, it is a custom

More honored in the breach than the observance. (I. iv. 12-16) 
The result of such liberal non-conformity is 'angst": "the awareness of one's freedom as radical possibility". viii Angst is the "price often demanded for such nonconformity as [Hamlet] sought in the manner of Socrates to harmonize his life with his philosophy" (Flynn, 2006: 25). However, angst is also the sign of authenticity of the self: "Have we any evidence of the possibility of authentic existence, Heidegger asks. Yes, Angst reveals to us this possibility" (Jaeger, 1952: 660). ${ }^{\text {ix }}$

Meanwhile, the fact that only Hamlet is able to communicate with the ghost of his father adds to this sense of anguish. According to Jean-Paul Sartre in Nausea, 'nothingness' is at the center of 'being'. The apparition is associated with this nothingness that fills Hamlet's being. For Sartre, humans are informed by the existentialist dialectic between being and nothingness. Nothingness lies at the heart of being. (The intermittent appearance of the ghost fills this ontological lack and makes Hamlet, at least for some quick moments, feel all at one.) As the play moves on, Hamlet finds courage to look at himself in the mirror of the other $^{\mathrm{x}}$ (which is a rare occasion and not everyone is able to do the same ${ }^{\mathrm{xi}}$ ). This is the moment of existential angst. "From this comes man's despair, but also, if he has courage, his existential integrity" (Sartre, 2000: 21). And Hamlet surely shows courage. Encountering the ghost, he says: "Why, what should be the fear? / I do not set my life at a pin's fee / And for my soul, what can it do to that / Being a thing immortal as itself ? / It waves me forth again. I'll follow it" (I. iv. 64-68). Thus Hamlet follows in the path of self-realization, of self-becoming.

Awareness of death pushes people to take action. (In the graveyard scene, Hamlet literally sits vis-a-vis death.) $\mathrm{He}$ is now aware that each individual must pass (unaccompanied) through the existential crisis: to gain consciousness of his existence, his mortality, the painful freedom to choose and act. Therefore, meaning takes shape through action, because existential philosophy holds that the world has no intrinsic meaning, and there is no essence before existence. And this is the reason behind that world-famous hesitation of Hamlet. He wants to choose authentically, to act authentically and not in bad faith. After all, "man's deepest concern is to realize his authentic self" (Jaeger, 1952: 660).

\section{Sadeq Hedayat and Buf-e Kur (The Blind Owl)}

Sadeq Hedayat (1903, Tehran - 1951, Paris) has been one of the main pillars of modernism in Persian fiction. He wrote his first collection of short stories, Zende be-Gur (Buried Alive) in 1930, upon his return from France. It was followed by Se Qatre Khun (Three Drops of Blood) in 1932, Sayeh Rowshan (Chiaroscuro) in 1933, and some other works. However, it was with his 1937 novel, The Blind Owl, that he became an acclaimed writer (it was praised by many famous writers including Ander Breton and Henry Miller ${ }^{\mathrm{xii}}$ ). Hedayat wrote The Blind $\mathrm{Owl}$ when he was in India studying "Middle Persian, a language he believed would allow him to recapture Iran's lost glory" (Rahimieh, 1994: 251).

Hedayat was not only familiar with Western literary forms, but he was also well-versed in classic Persian literature, mythology and folklore. He stood up against the ornate and grandiloquent style of traditional prose and instead used colloquial language in his fiction. By reason of his unorthodox views, he was and has remained to be among those figures in modern Persian literature who are most feared and most desired, most read and most misunderstood. As Jalal al-Ahmad has aptly mentioned, "Buf-e Kur [The Blind Owl] is the revenge of a man-who has become conscious of his mortality-on mundane, meaningless life and his surroundings" (Al-Ahmad, 1952: 67). Now let us examine the work itself.

Similar to Hamlet in his soliloquies, the narrator in The Blind $O w l$ is an 'alienated' character who is driven to talk to his shadow to get the burden of living off his chest. Therefore, as in Hamlet, the major question becomes 'to be or not to be.'

Hedayat's The Blind Owl (similar to Camus' L'Etranger, 1942) in the form of interior monologue. Like Meursault, Hedayat's narrator affects the reader as though he was narrating the story from a diary or his notebook, and the reader is not sure as to the origin of the narrative he is offered. The inevitable result is ambiguity, and this ambiguity

derives from his deliberate juxtaposition of dream and reality. [...] From this point, Hedayat quickly moves to his presentation of the existential message in Kafka. He speaks of the 'guilt of our existence' with which we are confronted at every turn. Hedayat sees humanity as totally alone and helpless without a guiding force or a higher spiritual and moral power ... [They] have only themselves to rely upon. (Rahimieh, 1994: 261-2)

Therefore, the major theme of the work is the existential anguish: the angst of being, the uncanny dread of death, and the anxiety of freedom to choose and act and be responsible.

The Blind $O w l$ begins with an oft-quoted paragraph which reveals the important existential theme of selfrealization and the agony of consciousness:

There are sores which slowly erode the mind in solitude like a kind of canker. It is impossible to convey a just idea of the agony which this disease can inflict. In general, people are apt to relegate such inconceivable sufferings to the category of the incredible. Any mention of them in conversation or in writing is considered in 
the light of current beliefs, the individual's personal beliefs in particular, and tends to provoke a smile of incredulity and derision. The reason for this incomprehension is that mankind has not yet discovered a cure for this disease. Relief from it is to be found only in the oblivion brought about by wine and in the artificial sleep induced by opium and similar narcotics. Alas, the effects of such medicines are only temporary. After a certain point, instead of alleviating the pain, they only intensify it. (Hedayat, 2010: 1)

This paragraph evokes the famous soliloquy of Hamlet when he ponders upon the condition of life and the anguish of existence. Like Hamlet, the narrator is wondering "Whether 'tis nobler in the mind to suffer / The slings and arrows of outrageous fortune / Or to take arms against a sea of troubles, / And by opposing end them? To die, to sleep [...] perchance to dream" (III. i.). In brief, one has to realize his own contingency. ${ }^{\mathrm{xv}}$

Another important motif in Hedayat's oeuvre is 'yet-to-come' death. Death is a reminder of life; it is a way of being, not a way to end. The uncanny dread of impending death is something of value for Hedayat. The narrator/main character of The Blind Owl says, "My one fear is that tomorrow I may die without having come to know myself," he even calls for death, "Death, death ... where are you ? The thought of death soothed me." He know that

The presence of death annihilates all superstitions. We are the children of death and it is death that rescues us from the deceptions of life. In the midst of life he calls us and summons us to him. At an age when we have not yet learnt the language of men if at times we pause in our play it is that we may listen to the voice of death.... Throughout our life death is beckoning to us. (Hedayat, 2010: 84)

This idea is in line with Heideggerian Sein-zum-Tode ('being-toward-death'): the immanence of death, the irreplaceability of death. ${ }^{\text {xvi }}$ Therefore, death becomes a phenomenon of life; it reveals the way we exist.

\section{Conclusion}

Goethe years ago proposed the idea of Weltiteratur, and his grand notion came to influence the field of comparative literature which has the power to cross the borderlines of cultures and nationalities in order to invite 'other' literatures. Today, comparative literature has joined forces with the ideas of intertextuality and dialogism to bring literatures of the world close together. In this big picture, all texts are affiliated, intertwined in a web; they create a network of literature, or as Spivak brilliantly puts, a 'planetarity'. ${ }^{\text {xii }}$

Having this planetary idea in mind, this paper aimed at exploring the key concepts of Existential thinking in two masterpieces of the world literature. Shakespeare's Hamlet and Hedayat's The Blind Owl are philosophically responsive and can be appropriated by various schools of philosophy or literary criticism and theory. The present research attempted to explore major existential themes in Shakespeare's Hamlet and Hedayat's The Blind Owl which pose fundamental questions about the nature of being and existence. Existential philosophy puts emphasis on the individual, their basic freedom and their passionate commitment to their choices and decisions. All these concepts are visible in Hamlet. The eponymous hero-on a quest to gain self-knowledge and consciousness - tries to find an answer to these questions: human's freedom to choose and act. By the end of the play, Hamlet is a transformed self. ${ }^{\text {xviii }}$ In act $\mathrm{V}$, we see a different Hamlet: he is not feigning madness anymore, nor does he show any sign of frustration or anger. "He has become himself. His task was never to imitate his father or act as his father's instrument. ${ }^{\text {xix }}$ This is a profound liberation and it is why Hamlet, notwithstanding the waste it portrays, is a great drama of individuality". ${ }^{\mathrm{xx}}$ The same motif can be seen in The Blind Owl. All in all, Hamlet and Hedayat's narratorprotagonist challenge audiences and readers to live authentically in a world that is inauthentic and false.

\section{References}

Al-Ahmad, J. (1952) "Hedayat Buf-e Kur," Elm va Zendegi [Science and Life], 1:1, p. 67.

Bloom, H. (1995) The Western Canon: the Books and Schools of the Ages. New York: Riverhead Books.

Camus, A. (2005) The Myth of Sisyphus. Trans. Justin O’Brien. London: Penguin.

Derrida, Jacques (1995) The Gift of Death. Trans. David Wills. Chicago and London: The University of Chicago Press.

Flynn, Th. R. (2006) Existentialism: A Very Short Introduction. Oxford: Oxford University Press.

Friedman, M. (1964) The Worlds of Existentialism. New York, Random House.

Galens D. (2000) Literary Movements for Students. 2 volumes. New York: Gale.

Glicksberg, Ch. I. (1948) “The Literature of Existentialism,” Prairie Schooner. Vol. 22: 3, pp. 231-237.

"Goft va Guyi miyane Henry Miller and Minoo Javan," [“Minoo Javan's Interview with Henry Miller"], Sokhan, 15:7 (1965): pp. 729-730.

Grene, M. (1948) Introduction to Existentialism. London and Chicago: University of Chicago Press.

Hedayat, S. (2010) The Blind Owl. Trans. D. P. Costello. New York: Grove Press. 
Heidegger, M. (2001) Being and Time. Trans. John Macquarrie and Edward Robinson. London: Blackwell.

Holbrook, P. (2010) Shakespeare's Individualism. Cambridge: Cambridge University Press.

Jaeger, H. (1952) "Heidegger's Existential Philosophy and Modern German Literature," PMLA. 67: 5, pp. 655-683.

Lashgari, D. (1982) "Absurdity and Creation in the Work of Sadeq Hedayat," Iranian Studies. 15: 1/4, pp. $31-52$.

Levinas, E. (1987) Time and the Other. Trans. Richard A. Cohen. Pittsburgh, PA: Duquesne University Press.

Rahimieh, N. (1994) "Die Verwandlung Deterritorialized: Hedayat's Appropriation of Kafka," Comparative Literature Studies. 31: 3, pp. 251-269.

Sartre, J.(2000) Nausea. Trans. Robert Baldick. London: Penguin.

Shakespeare, W. (2003) The Tragedy of Hamlet: Prince of Denmark. With an essay by Harold Bloom. New Haven and London: Yale University Press.

Shakespeare, W. (2004) Romeo and Juliet. With an essay by Harold Bloom. New Haven and London: Yale University Press.

Shakespeare, W. (2005) Julius Caesar. San Diego, CA: ICON Group International, Inc.

Shakespeare, W. (2007) King Lear. With an essay by Harold Bloom. New Haven and London: Yale University Press.

Spivak, G. Ch. (2003) Death of a Discipline. New York: Columbia University Press.

\section{Notes}

${ }^{i}$ Harold Bloom believes that Shakespeare is the real inventor of psychoanalysis, not Freud; Freud was only its codifier or law-giver. "Freud, as prose-poet of the post-Shakespearean, sails in Shakespeare's wake; and the anxiety of influence has no more distinguished sufferer in our time than the founder of psychoanalysis, who always discovered that Shakespeare had been there before him" (Bloom, 1995: 363).

${ }^{\text {ii }}$ Ralph Waldo Emerson (1803-1882) — famous writer and leading exponent of transcendentalism—declared: "Now, Literature, philosophy, and thought are Shakespearized. His mind is the horizon beyond which, at present, we do not see" (cited in Bloom, 1995: 366).

iii Martin Heidegger. Being and Time. Trans. John Macquarrie \& Edward Robinson. London: Blackwell, p. 26.

iv As Maurice Friedman in The Worlds of Existentialism (1964) brilliantly puts, "The very notion that existentialism is something that can be defined in a catch phrase, or that one can merely know about it without understanding it from within, has made it, for some people, into an intellectual fad and robbed it of its proper seriousness" (3).

${ }^{\mathrm{v}}$ In Culture and Anarchy (1869), Matthew Arnold contrasted Hellenism (the life of intellect, freedom and beauty) with Hebraism (the life of moral obedience) in his portrait of the two opposing ideals within Western culture. Therefore, if there is any hint of fatalism in Romeo and Juliet, it is because the play follow the Medieval mindset: thinking in terms of absolutes, while Hamlet reflects more and more this greater movement toward a more relative and flexible view of human nature and human conduct (which is a Hellenistic feature).

${ }^{v i}$ Harold Bloom in his magnificent book, The Western Canon: the Books and Schools of the Ages (1995), poses a thought-provoking question: 'If 'social energies' [New Historicists' favorite term] wrote King Lear and Hamlet, why exactly were social energies more productive in the son of the Stratford artisan than in the burly bricklayer Ben Jonson?" (56).

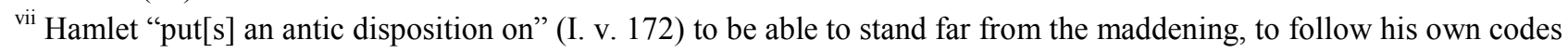
of behavior, and above all to act authentically. As Carl Jaspers says: "Existenz is present when I am authentic" (qtd. in Gallens, 2002, 2 ${ }^{\text {nd }}$ Vol. : 69).

viii Thomas R. Flynn, Existentialism, p. 133. Angst is different from 'fear' which has a specific object. "Thus one might fear falling off a cliff but feel anguish before the possibility of throwing oneself over" (Ibid).

${ }^{\text {ix }}$ In a state of angst we face our true, free being. "Existential angst is, rather, a sense of freedom, of a capacity to strike out on one's own in the formation of a scheme of beliefs and values" (David Galens, Literary Movements for Students. 2 volumes. New York: Gale: 2002, p. 74). Such a person/character is not chained to the world and worldly affairs; he knows "how weary, stale, flat and unprofitable ... all the uses of the world" would be (Hamlet, I. ii. 133-4).

${ }^{x}$ Nietzsche said Hamlet delays his revenge because "he has peered into the 'abyss' of being" (Holbrook, 2010: 46).

${ }^{x i}$ Remember the scene when Hamlet goes to Gertrude's chamber and the ghost appears to him, and it is only Hamlet who is able to see the apparition, not Gertrude (Act 3, scene 4).

Gertrude: $\quad$ To whom do you speak this?

Hamlet: $\quad$ Do you see nothing there?

Gertrude: $\quad$ Nothing at all. Yet all that is I see. 
Hamlet: $\quad$ Nor did you nothing hear?

Gertrude: $\quad$ No, nothing but ourselves. (III. iv. 131-5)

Hamlet later refers to the reason why Gertrude cannot see her late husband's ghost:

Hamlet: $\quad \mathrm{O}$, throw away the worser part of it [heart]

And live the purer with the other half.

xii “Goft va Guyi miyane Henry Miller and Minoo Javan,” (Minoo Javan's Interview with Henry Miller), Sokhan, 15:7 (1965), pp. 729-730. According to Sokhan, Henry Miller, praising Hedayat's masterpiece, says: "I have not seen the like of it in any language; I wish to write something like that" (Ibid).

xiii Professor Nasrin Rahimieh in her article "Die Verwandlung Deterritorialized: Hedayat's Appropriation of Kafka" (1994) has referred to "the manner in which Hedayat detached Kafka's text ["Metamorphosis"] from the linguistic, literary, and cultural system into which Kafka had inscribed it and appropriated it for his own purposes." Rahimieh also asserts that Hedayat used "Kafka's text to the extent that it enabled him to bring it in line with his own vision of the prevalent condition of minority in Persian prose literature" (252-4).

${ }^{\text {xiv }}$ Rahimieh also believes that "alienation and existential angst was a necessary catalyst for Hedayat's creativity, because Hedayat was engaged in a rebellion against his own literary and cultural tradition" (265).

${ }^{\mathrm{xv}}$ Existentialist works (such as the opuses of Hedayat, Kafka or Camus) depict man as thrown out into the world like an 'unwelcome guest' (Heideggerian Dasein). Therefore, the idea of man as 'being-in-the-world' stands against Cartesian cogito and its ensuing duality of body and mind, because man is not an abstract entity, not a pre-given essence. We exist first and determine our essence by our choosing. Thus, the first step in living authentically is self-awareness.

xvi Jacques Derrida has written a splendid long essay, entitled "Donner la mort", which is translated as The Gift of Death. Derrida, drawing on Heidegger, talks about the concept of dying for the other. Heidegger is quoted as saying, "No one can take the Other's dying away from him" (Jacques Derrida, The Gift of Death. Trans. David Wills, Chicago and London: The University of Chicago Press, 1995, p. 42).

xvii "I propose the planet to overwrite the globe. Globalization is the imposition of the same system of exchange everywhere. [...]The globe is on our computers. No one lives there. It allows us to think that we can aim to control it. The planet is in the species of alterity, belonging to another system; and yet we inhabit it, on loan. [...]

To be human is to be intended toward the other.

[...] If we imagine ourselves as planetary subjects rather than global agents, planetary creatures rather than global entities, alterity remains underived from us; $[\ldots]$ We must persistently educate ourselves into this peculiar mindset" (Spivak, 2003, 72-3).

xviii "It is a critical commonplace to assert that the Hamlet of act 5 is a changed man: mature rather than youthful, certainly quieter, if not quietistic, and somehow more attuned to divinity. Perhaps the truth is that he is at last himself" (Bloom, Essay on Shakespeare's Hamlet. p. 229).

${ }^{\text {xix }}$ Hamlet tries not to follow blindly in the footsteps of others, not even his father's. That is why his final act of taking revenge has his own signature, not his father's. He strives to live by his own rules and ideals; therefore, he does not rush into taking revenge. Remember Nietzsche's notorious attack on 'herd morality' or his distinction between 'slave morality' and 'master morality'. Hamlet simply does not want to be one of the 'herd'. Besides, we should notice that Hamlet never vows to a bloody revenge; he only promises to remember:

Ghost:

Fare thee well at once!

The glow-worm shows the matin to be near,

And begins to pale his uneffectual fire.

Adieu, adieu, adieu. Remember me. (I. v. 88-91)

${ }^{\mathrm{xx}}$ Peter Holbrook, Shakespeare's Individualism, p. 91. 